\title{
Modification and Application of Albizia lebbeck Sawdust For The Sorption of Lead(II) and Copper(II) From Aqueous Solutions
}

\author{
MOHAMMAD NURNABI ${ }^{1 *}$, SNAHASISH BHOWMIK², MD. SIRAJUR RAHMAN ${ }^{1}$, \\ TASRINA RABIA CHOUDHURY ${ }^{3}$, ANDREW J. PARSONS ${ }^{4}$ and SCOTT D. YOUNG ${ }^{5}$
}

\author{
'Department of Applied Chemistry and Chemical Engineering, \\ University of Dhaka, Dhaka 1000, Bangladesh. \\ ${ }^{2}$ Department of Applied Chemistry and Chemical Engineering, \\ Noakhali Science and Technology University, Noakhali, Bangladesh. \\ ${ }^{3}$ Analytical Chemistry Laboratory, Chemistry Division, Atomic Energy Centre, \\ Dhaka, Bangladesh. \\ ${ }^{4}$ Division of Materials, Mechanics and Structures, Faculty of Engineering, \\ University of Nottingham, United Kingdom. \\ ${ }^{5}$ Department of Environmental Science, University of Nottingham, United Kingdom. \\ ${ }^{*}$ Corresponding author E-mail: nnabi@ du.ac.bd \\ http://dx.doi.org/10.13005/ojc/360401
}

(Received: June 04, 2020; Accepted: July 05, 2020)

\begin{abstract}
Sawdust of Albizia lebbeck (locally known as koroi) was modified by treatment with sodium methylate followed by reactions with epichlorohydrin and $n$-dodecylamine to afford the sorbent which was termed as DDA-SD. The sorbent was characterized with the help of FTIR (ATR), SEM and chemical test. It was then used for the sorption of $\mathrm{Pb}^{2+}$ and $\mathrm{Cu}^{2+}$ from aqueous solutions and the effects of solution $\mathrm{pH}$, dosage of sorbent, initial metal ions concentration and contact time were enumerated. The sorption data were tested for Langmuir and Freundlich isotherm models and found that the process followed Langmuir model and the maximum sorption capacities were calculated as $17.37 \mathrm{mg} / \mathrm{g}$ and $9.4 \mathrm{mg} / \mathrm{g}$ for $\mathrm{Pb}^{2+}$ and $\mathrm{Cu}^{2+}$ ions respectively. The sorption data were also tested for pseudo-first order and pseudo-second order kinetic models and the data fitted well with pseudo second order kinetics. Exhausted DDA-SD adsorbent can be regenerated using $0.1 \mathrm{M} \mathrm{HCl}$ or $0.1 \mathrm{M}$ $\mathrm{HNO}_{3}$ followed by wash with deionized water and reused for further adsorption purpose.
\end{abstract}

Keywords: Non-biodegradable, Etherification, Epichlorohydrin, Epoxy moiety, Morphology.

\section{INTRODUCTION}

Disposal of untreated industrial wastes is the major source of heavy metals contamination, which causes severe water, soil and air pollution.
The persistent nature of heavy metals results their accumulation in plants and animal tissues and ultimately enter the food chain. When heavy metals enter into human body through contaminated foods, they are bio-amplified and cause serious threat to

This is an Open Access article licensed under a Creative Commons license: Attribution 4.0 International (CC- BY). Published by Oriental Scientific Publishing Company @ 2018

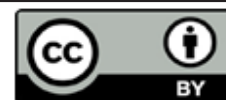


the public health ${ }^{1-2}$. From various industrial activities lead and copper are exposed to the environment and cause detrimental effects such as malfunction of brain, cognitive disorder to the children, renal diseases, anemia and loss of reproductive power ${ }^{3}$. Many techniques such as precipitation, ion-exchange, membrane separation, electrodialysis, extraction etc. are reported for removing heavy metals ${ }^{4,5}$. However, these techniques are not attractive because of high cost and difficulties associated with the handling of toxic sludges produced during the processes ${ }^{1,4,6}$. Adsorption processes have drawn much attention due to their high efficacy in removing heavy metals ${ }^{4}$ and availability of a wide variety of adsorbents such as activated carbon ${ }^{7}$, clay minerals ${ }^{8-9}$, zeolites ${ }^{10}$, metal oxides ${ }^{11-12}$, agricultural wastes ${ }^{13-20}$, biomass ${ }^{21}$ polymeric materials ${ }^{22}$, which demonstrated significant adsorption capacities for heavy metals. Although activated carbon possesses very high adsorption capacities for various organic compounds and dyes, it is not that effective in removing heavy metals. Moreover, activated carbon is too expensive and thus has found less application in removing heavy metals ${ }^{4}$. On the other hand, the use of untreated plant wastes were reported to have poor sorption capacities and releases soluble organic substances and make the treated water unsuitable for uses ${ }^{23,24}$. During chemical treatment of plant materials most of the soluble organic materials are removed and simultaneously the metal sorption capacity is enhanced ${ }^{4}$.

Sawdust is a by-product of wood industries and can be obtained at negligible cost. Earlier sawdust of different plants were chemically modified using a variety of reagents and applied for sequestration of metals ions, e.g. alkali treated sawdusts demonstrated adsorption capacities of $6.92 \mathrm{mg} / \mathrm{g}$ and $15.8 \mathrm{mg} / \mathrm{g}$ of $\mathrm{Cu}^{2+}$ and $\mathrm{Zn}^{2+}$ respectively ${ }^{25}$, while acid treated sawdust showed $\mathrm{Cu}^{2+}$ adsorption capacities of 3.6-13.95 mg/g $/ \mathrm{g}^{26-28}$. Few research groups adopted treatment method using formaldehyde in sulfuric acid to enhance the adsorption capacity of sawdust but ended with poor results ${ }^{29-31}$. Recently we observed that sawdust impregnated with nano-zerovalent iron showed significant sorption of As(III) from aqueous solution ${ }^{32}$. Other recent studies showed that sawdust ${ }^{33}$, nano-sawdust ${ }^{34}$, sawdust-kaolinite composite ${ }^{35}$ could be used as adsorbents for heavy metals. Modification of pure cellulose were reported to have good to excellent adsorption capacities of heavy metals, e.g etherification of cellulose with epichlorohydrin followed by epoxide ring opening by polyethyleneimine afforded an adsorbent that showed moderate adsorption capacities of $25 \mathrm{mg} / \mathrm{g}$ and $15 \mathrm{mg} / \mathrm{g}$ of $\mathrm{Pb}^{2+}$ and $\mathrm{Cu}^{2+}$ respectively ${ }^{36}$. An adsorbent prepared by oxidation of pure cellulose with periodate and hydroxamic acid demonstrated excellent $\mathrm{Cu}^{2+}$ sorption capacity of $246 \mathrm{mg} / \mathrm{g}^{37}$.

To the best of our knowledge no report is available on the development of adsorbent for heavy metal by modification of sawdust using etherification followed by ring opening by an alkyl amine strategy. In the present investigation modification of sawdust of Albizia lebbeck was carried out by treatment with sodium methylate, followed by etherification using epichlorohydrin and oxirane ring opening by n-dodecylamine to afford a material, which was applied for the sorption of $\mathrm{Cu}^{2+}$ and $\mathrm{Pb}^{2+}$ ions.

\section{MATERIALS AND METHODS}

\section{Materials and reagents}

Sawdust of Albizia lebbeck (Local name Koroi) obtained from a sawmill located at Mirpur in Dhaka, Bangladesh was washed with water and sundried for 3 days followed by drying in an oven at $50^{\circ} \mathrm{C}$ for $72 \mathrm{~h}$ and cooled in desiccators. The dried material was sieved and the fraction with a particle size between 0.2 and $0.6 \mathrm{~mm}$ was used for the preparation of chemically modified adsorbent. Chemical analyses of dried sawdust were carried out using literature methods ${ }^{38}$ and found that it contained $7.25 \%$ extractible materials, $68.7 \%$ cellulose and $17 \%$ lignin.

Sodium methylate, dimethylsulfoxide (DMSO), epichlorohydrin, ethanol, n-dodecylamine, copper sulfate pentahydrate, lead nitrate, sodium hydroxide and nitric acid were purchased from Aldrich and used as received. Stock solutions of the metals were obtained by dissolving required amounts of $\mathrm{CuSO}_{4} \cdot 5 \mathrm{H}_{2} \mathrm{O}$ and $\mathrm{Pb}\left(\mathrm{NO}_{3}\right)_{2}$ in deionized (DI) water. A small volume (10-20 $\mu$ l) of $0.1 \mathrm{M} \mathrm{NaOH}$ or $0.1 \mathrm{M} \mathrm{HNO}_{3}$ were added to the metal ions solutions to adjust the $\mathrm{pH}$.

\section{Preparation of the adsorbent}

Modification of sawdust was carried out following a literature procedure ${ }^{36}$. In brief, sawdust $(5.0 \mathrm{~g})$ was suspended in DMSO $(100 \mathrm{~mL})$, purged with $\mathrm{N}_{2}$ and stirred in a hot plate magnetic stirrer 
for $2 \mathrm{~h}$ at $60^{\circ} \mathrm{C}$. The mixture was cooled to room temperature, treated with sodium methylate $(15.0 \mathrm{~g})$ and stirred for $1 \mathrm{~h}$ in $\mathrm{N}_{2}$ atmosphere. The resulting solids were separated by filtration and washed with DI water $(200 \mathrm{~mL})$ and dried at $50^{\circ} \mathrm{C}$ for $3 \mathrm{~h}$ to afford the material $\mathrm{NaO}-\mathrm{SD}(4.5 \mathrm{~g})$. To the suspension of $\mathrm{NaO}-\mathrm{SD}(3.0 \mathrm{~g})$ in DMSO $(50 \mathrm{ml})$ epichlorohydrin $(30 \mathrm{~mL})$ was added and stirred for $2 \mathrm{~h}$ at $50^{\circ} \mathrm{C}$ in $\mathrm{N}_{2}$ atmosphere. Solid materials thus obtained were separated by filtration and washed with DI water and dried at $50^{\circ} \mathrm{C}$ for $3 \mathrm{~h}$ to afford $\mathrm{ECH}-\mathrm{SD}$ (3.12 g). ECH-SD (1.4 g) was suspended in DMSO $(30 \mathrm{~mL})$, n-dodecylamine $(3.2 \mathrm{~g})$ was added in portions and heated at $100^{\circ} \mathrm{C}$ with stirring for 18 hours. The final material was separated by filtration and washed with DI water and dried in an oven at $50^{\circ} \mathrm{C}$ for $3 \mathrm{~h}$ and cooled in desiccators to afford the sorbent DDA-SD $(1.4 \mathrm{~g})$.

\section{Instruments}

The functional groups present in the sorbent (DDA-SD) were identified by FTIR-ATR (Shimadzu, Japan) and the surface morphology of it was determined using a scanning electron microscope (Philips XL30, FEI, USA). The surface area was determined by BET analysis, which was performed on a Quantachrome Autosorb-1. For BET experiment DDA-SD sample were out gassed at $120^{\circ} \mathrm{C}$ for $24 \mathrm{~h}$ before analysis and Krypton gas was used as the adsorbent. To obtain a value of surface area, 11 points were measured in the standard range of $(\mathrm{P} / \mathrm{Po})=$ 0.05 to 0.3 . The $\mathrm{pH}$ of the solutions was measured with a pH meter (HI 2211-02, Hanna, Romania). Batch adsorption experiments were performed under shaking in an orbital Shaker (SSL1, Stuart UK). Metal ions concentrations of the filtered solutions (Whatman 41) were measured with Atomic Absorption Spectroscopy (AAS) (Varian AA 240 FS, USA).

\section{Batch sorption experiments}

Metal uptake capacities of the DDA-SD were determined by adding $100 \mathrm{mg}$ of DDA-SD into $100 \mathrm{~mL}$ of metal ion solution taken in a conical flask. The experiments were carried out at $25^{\circ} \mathrm{C}$ under shaking at $180 \mathrm{rpm}$ in an orbital shaker. After completion of the experiments the solutions were filtered with Whatman 41 filter paper and the filtrates were then analyzed with AAS. The sorption capacity, $\mathrm{q}_{\mathrm{e}}$ was determined according to the equation (1).

$q_{e}=\frac{\left(C_{i}-C_{e}\right) \times V}{m}$
Where $\mathrm{Ci}$ and $\mathrm{Ce}$ stand for initial and equilibrium concentrations of the metal ion $(\mathrm{g} / \mathrm{L}), \mathrm{m}$ represents mass of the adsorbent $(\mathrm{g})$ and $\mathrm{V}$ is the volume of the solution (L).

To observe the effect of $\mathrm{pH}$ on the sorption process $100 \mathrm{~mL}$ of a metal ion solutions were taken in different conical flasks, $\mathrm{pH}$ were adjusted 1.9-6 for $\mathrm{Pb}$ (II) and 3-10.2 for $\mathrm{Cu}$ (II) by adding dilute nitric acid or sodium hydroxide and $100 \mathrm{mg}$ of DDA-SD was added to each flask and left under shaking for 1 hour. Afterwards sorbents were separated by filtration and sorption capacities were calculated using the equation (1).

Effect of dosage was investigated by adding different amounts of the DDA-SD (50-350 mg) to $100 \mathrm{~mL}$ metal ion solutions of fixed concentration (25.0 ppm) in different conical flasks, $\mathrm{pH}$ were adjusted 5.8 and 7.1 for $\mathrm{Pb}^{2+}$ and $\mathrm{Cu}^{2+}$ respectively. Effect of contact time was monitored by adding fixed amount of the sorbent $(500 \mathrm{mg})$ to metal ion solutions of concentrations of 23.5, 38.0 ppm for $\mathrm{Cu}^{2+}$ and 9.5, $28.5 \mathrm{ppm}$ for $\mathrm{Pb}^{2+}$ and $\mathrm{pH}$ were maintained at 5.8 for $\mathrm{Pb}^{2+}$ and 7.1 for $\mathrm{Cu}^{2+}$ and left under shaking. Aliquots of $2 \mathrm{~mL}$ were drawn at different time intervals and metal ion concentrations were measured by AAS.

\section{Desorption study}

Desorption study was conducted by soaking $20 \mathrm{mg}$ of the exhausted DDA-SD in $20 \mathrm{~mL}$ of $0.1 \mathrm{M} \mathrm{HNO}_{3}$ or $0.1 \mathrm{M} \mathrm{HCl}$ and left under shaking for 3 hours. An aliquot of $0.5 \mathrm{~mL}$ was drawn in every $30 \mathrm{~min}$ and metal ion concentrations were analyzed using AAS.

\section{RESULTS AND DISCUSSION}

\section{Synthesis of the adsorbent}

The major chemical constituents of sawdust are cellulose, lignin and hemicellulose. The reactions occurred during the modification process are represented in the scheme 1 . The primary hydroxyl group of the $\beta$ unit (1-4 linked D-glucose) of cellulose reacted with sodium methylate to afford Cell- $\mathrm{CH}_{2}-$ $\mathrm{ONa}(\mathrm{NaO}-\mathrm{SD})$. During treatment with sodium methylate in DMSO a considerable amount of extractible materials, hemicellulose and lignin were removed from the cellulosic material ${ }^{38}$. Cell- $\mathrm{CH}_{2}-\mathrm{ONa}$ then reacted with epichlorohydrin to afford cellulose derivative containing oxirane moiety $(\mathrm{ECH}-\mathrm{SD})$. The 
oxirane ring was opened by reaction with n-dodecyl amine to afford the sorbent (DDA-SD).

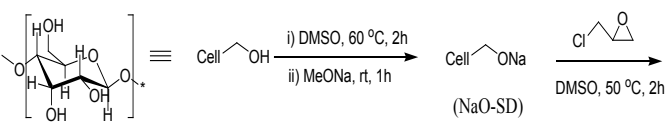

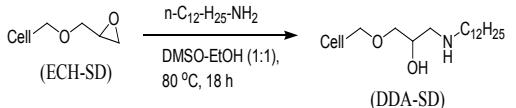

Scheme 1. Modification of sawdust

\section{Characterization}

FTIR Analysis: FTIR analysis of $\mathrm{NaO}-\mathrm{SD}$, ECH-SD and DDA-SD were carried out using ATR sampling technique and vibrational frequencies are summarized in the Table 1.

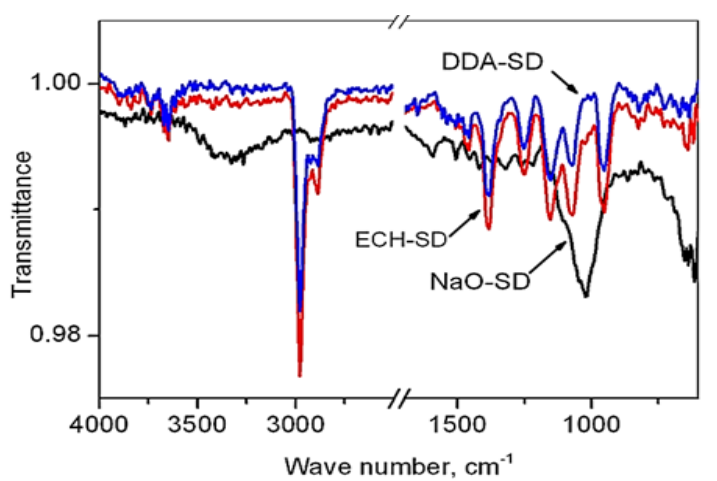

Fig. 1. FTIR spectra of NaO-SD, ECH-SD and DDA-SD

Table 1: FTIR peaks for synthesized materials

\begin{tabular}{ll}
\hline Material & \multicolumn{1}{c}{$v$ cm $^{-1}$} \\
\hline NaO-SD & $3587-3033,2925-2825,1590,1508$, \\
& $1458,1420,1325,1262,1218,1016,638$. \\
ECH-SD & $3700-3400,2976,2888,1458,1388$, \\
& $1250,1155,1073,954,821,638$. \\
DDA-SD & $3700-3490,2976,2888,1458,1388$, \\
& $1250,1155,1073,954,821,669,638$. \\
\hline
\end{tabular}

For $\mathrm{NaO}-\mathrm{SD}$ the prominent peaks appeared at 1016 (strong), 1250, 1458, 2825-2925 and 3033-3587 $\mathrm{cm}^{-1}$ which are assignable to the $\mathrm{C}-\mathrm{O}, \mathrm{C}-\mathrm{C}, \mathrm{C}-\mathrm{H}$, and $\mathrm{OH}$ stretching vibrations of the cellulose moiety. For $\mathrm{ECH}$ $\mathrm{SD}$ the $\mathrm{C}-\mathrm{O}, \mathrm{C}-\mathrm{C}, \mathrm{C}-\mathrm{H}$, and $\mathrm{OH}$ stretching vibrations were observed at 1073, 1250, 1458, 2888, 2976 and $3400-3700 \mathrm{~cm}^{-1}$, while those peaks for DDA-SD were at $1073,1250,1458,2888,2976$ and $3490-3700 \mathrm{~cm}^{-1}$. New peaks at 954 and $821 \mathrm{~cm}^{-1}$ were present in case of ECH-SD and DDA-SD which are assignable to the presence of the oxirane moiety.

The presence of an epoxy group in the $\mathrm{ECH}-\mathrm{SD}$ was further confirmed by a chemical method $^{36}$. On the treatment of ECH-SD with sodium thiosulfate the oxirane ring breaks down and liberates an equimolar amount of $\mathrm{NaOH}$ which can be quantified by titration with standardized $\mathrm{HCl}$ in presence of phenolphthalein indicator. Using this strategy the amount of epoxide ring $(\mathrm{mg})$ per gm of DDA-SD was determined by using the following equation (2). The amount of epoxide moiety was found to be $0.37 \mathrm{mg} / \mathrm{g}$ which was in good agreement with the previous result ${ }^{36}$.

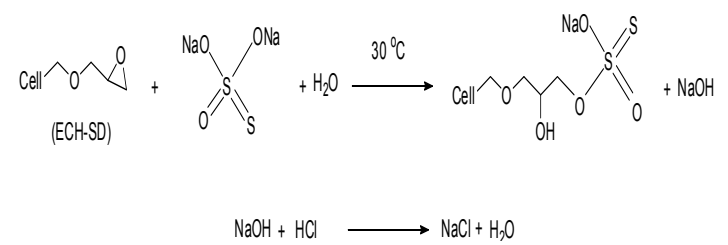

Scheme 2. Reaction of epoxide ring with sodium thiosulfate

Epoxide $=\frac{V \times M \times 58 \times 1000}{W}$

Where $\mathrm{V}=$ Volume $(\mathrm{mL})$ of $\mathrm{HCl}$ required, $\mathrm{M}$ $=$ molarity of $\mathrm{HCl}, \mathrm{W}=$ Weight $(\mathrm{gm})$ of treated sawdust (ECH-SD).

\section{SEM Analysis}

SEM images of NaO-SD and DDA-SD revealed similar morphology with rough surfaces in both cases (Figure 2).

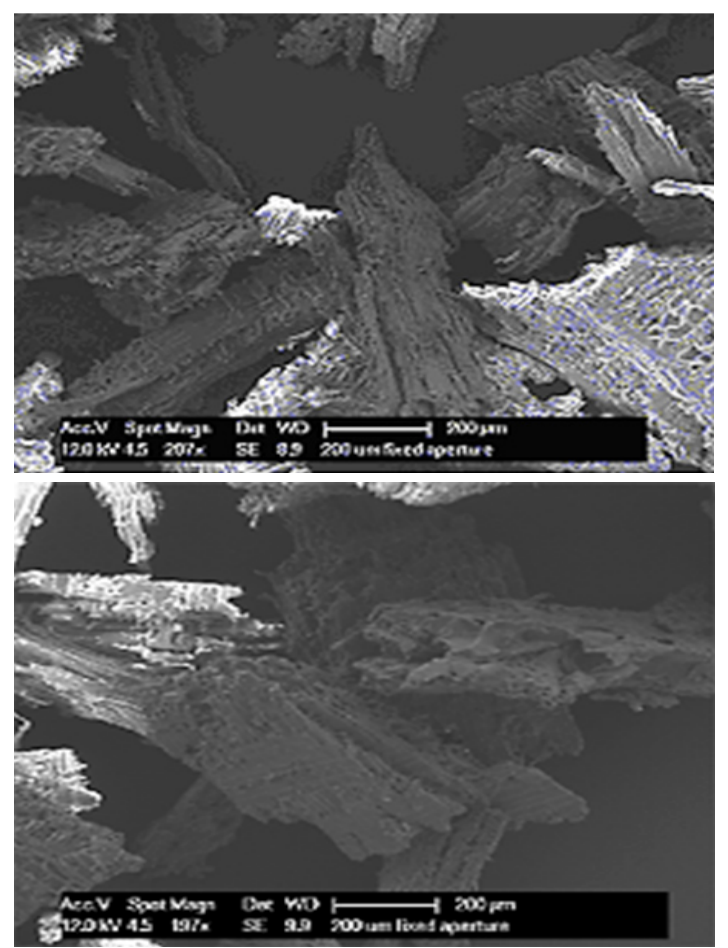

Fig. 2. SEM images of Na-SD (top) and DDA-SD (bottom) 


\section{Surface Area}

The surface area of NaO-SD and DDA-SD were measured by BET analysis and found to be $0.75 \mathrm{~m}^{2} / \mathrm{g}$ and $0.73 \mathrm{~m}^{2} / \mathrm{g}$ respectively, which revealed that the materials have comparable surface areas.

\section{Effect of $\mathrm{pH}$}

Depending on the $\mathrm{pH}$ of the solution the surface charge of an adsorbent varies significantly, which plays a vital role in the sorption process. The effect of $\mathrm{pH}$ on the sorption of $\mathrm{Pb}^{2+}$ and $\mathrm{Cu}^{2+}$ was studied by adding a constant dosage of DDA-SD $(20 \mathrm{mg} / 20 \mathrm{~mL}$ ) into and metal ion solutions of fixed concentrations ( $50 \mathrm{ppm}$ for $\mathrm{Pb}^{2+}$ and $5 \mathrm{ppm}$ for $\mathrm{Cu}^{2+}$ ) in different conical flasks maintaining $\mathrm{pH}$ in the range of 1.9 to 10 . The result showed that with increasing $\mathrm{pH}$ the sorption of $\mathrm{Pb}^{2+}$ increased dramatically and reached the maximum at $\mathrm{pH}$ 5.9. Effect of further increase of $\mathrm{pH}$ was not monitored as $\mathrm{Pb}^{2+}$ precipitated beyond the $\mathrm{pH}$ of 5.9. In case of $\mathrm{Cu}^{2+}$ the maximum sorption was achieved at $\mathrm{pH} 7.1$ and it remained same up to the $\mathrm{pH} \mathrm{10}$. It is assumed that at low $\mathrm{pH}$ some of the $\mathrm{NH}$ groups of DDA-SD were protonated, which hindered the chelation of metal ions and resulted lower sorption (Scheme 3).

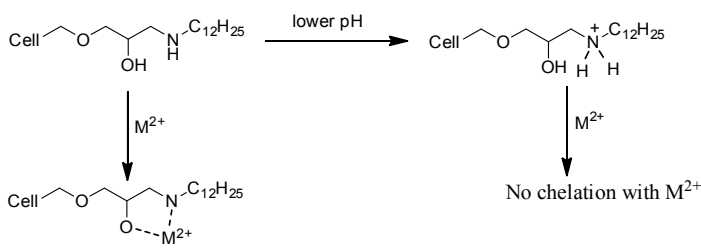

Scheme 3. Sorption mechanism at different $\mathrm{pH}$

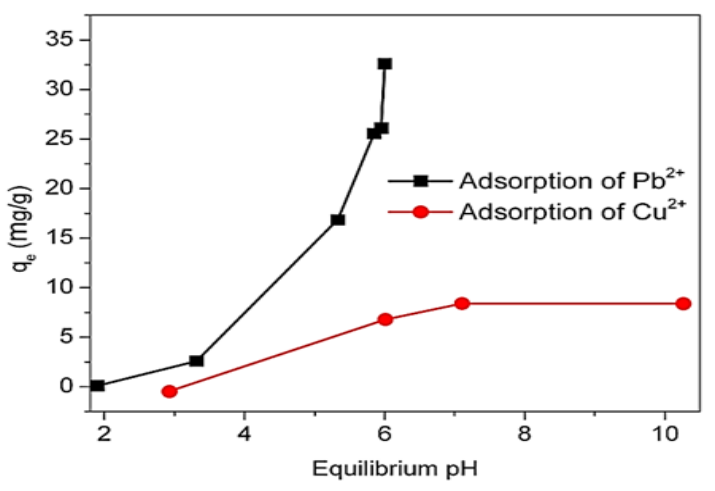

Fig. 3. Effect of $\mathrm{pH}$ on sorption of $\mathrm{Pb}^{2+}$ and $\mathrm{Cu}^{2+}$ on DDA-SD

\section{Effect of dosages}

The effect of dosages on the sorption of $\mathrm{Pb}^{2+}$ was carried out using DDA-SD dosages ranging from $0.5 \mathrm{~g} / \mathrm{L}$ to $3.5 \mathrm{~g} / \mathrm{L}$ at $\mathrm{pH} 5.85$ and at room temperature. The experiments were carried out under shaking in an orbital shaker at rpm 180 for 1 hours. The change in removal efficiency (\%R.E) and sorption capacity of DDA-SD for $\mathrm{Pb}^{2+}$ with the adsorbent dosages are shown in the Figure 4.

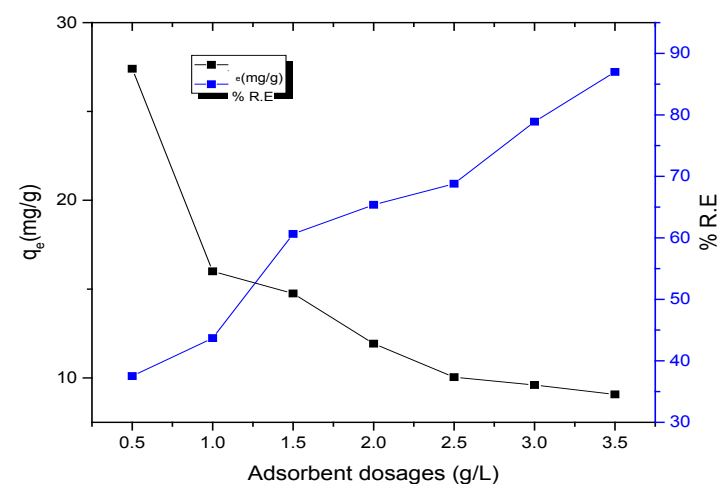

Fig 4. Effect of dosages of DDA-SD on the $\mathrm{Pb}^{2+}$ sorption

It is clear that sorption capacity decreased with the increasing amounts of dosage and maximum adsorption capacity was obtained at a dosage of $0.5 \mathrm{~g} / \mathrm{L}$ (Fig. 4). This is because almost all the active sites of sorbent was efficiently occupied by $\mathrm{Pb}^{2+}$ ions and at higher dosage although the number of active sites increased a situation was created where a surplus of adsorption sites existed and resulted lower sorption capacity.

\section{Effect of Time}

The equilibration time is considered as the optimum contact time, which was determined by measuring the sorption capacities at different time. In a conical flask $500 \mathrm{~mL}$ of the metal ion solution was taken, the $\mathrm{pH}$ was adjusted ( 5.9 for $\mathrm{Pb}^{2+}$ and 7.1 for $\mathrm{Cu}^{2+}$ ) and $500 \mathrm{mg}$ of DDA-SD was added. The solution was left under shaking and an aliquot of $2 \mathrm{~mL}$ was withdrawn at different time intervals, filtered, analyzed by AAS and the results are shown in the Fig. 5. It was evident that for all experiments the equilibration time was 60 minutes. It was also found that the sorption capacity of DDA-SD increased with increasing metal ion concentration, thus sorption capacity of $\mathrm{Pb}^{2+}$ increased from $7.97 \mathrm{mg} / \mathrm{g}$ to 17.47 $\mathrm{mg} / \mathrm{g}$ as the concentration was raised from $9.5 \mathrm{ppm}$ to $28.5 \mathrm{ppm}$, while that for $\mathrm{Cu}^{2+}$ increased from 10.32 $\mathrm{mg} / \mathrm{g}$ to $17.8 \mathrm{mg} / \mathrm{g}$ when the concentration was increased from 23.5 to $38 \mathrm{ppm}$. The higher sorption capacity at higher concentration is attributed to the higher probability of collision between sorbate and sorbent surface ${ }^{39}$. 


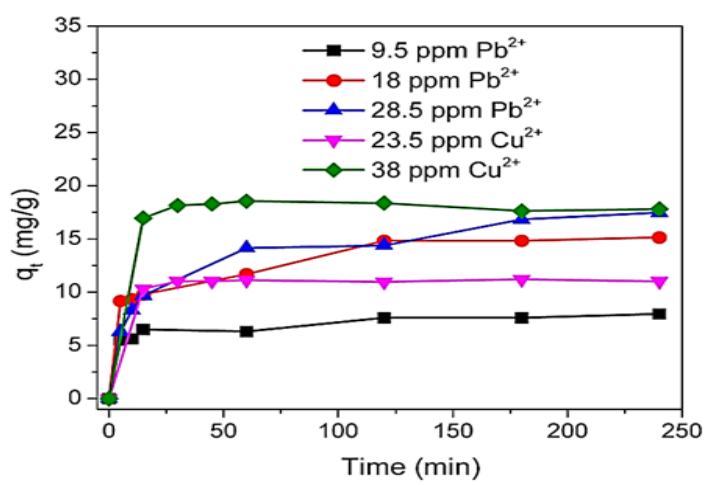

Fig. 5. Effect of concentration and time of the sorption of $\mathrm{Pb}^{2+}$ and $\mathrm{Cu}^{2+}$ on DDA-SD

\section{Adsorption isotherms}

The relationship between the amount of sorbate attached on the surface of a sorbent and its concentration in the equilibrium solution at a constant temperature is represented by sorption isotherm. Fig. 6 shows the equilibrium sorption data for $\mathrm{Pb}^{2+}$ and $\mathrm{Cu}^{2+}$ on DDA-SD.

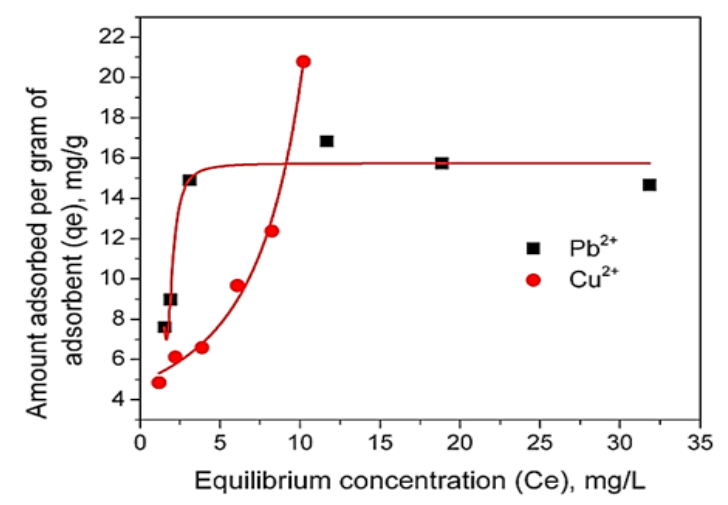

Fig. 6. Equilibrium adsorption isotherms for $\mathrm{Pb}^{2+}$ and $\mathrm{Cu}^{2+}$ on DDA-SD

The relationship between the equilibrium sorption capacities, $q_{e}(\mathrm{mg} / \mathrm{g})$ with the metal ion concentrations at equilibrium, $\mathrm{C}_{\mathrm{e}}(\mathrm{mg} / \mathrm{L})$ can be obtained by using Langmuir (equ.3) and Freundlich (equ. 4) isotherm models.

$\frac{C_{e}}{q_{e}}=\frac{C_{e}}{\mathrm{q}_{\max }}+\frac{1}{q_{\max } K_{L}}$

Where $\mathrm{C}_{\mathrm{e}}$ is the equilibrium concentration of sorbate $\left(\mathrm{mg} . \mathrm{L}^{-1}\right)$; qe is the equilibrium sorption capacity $\left(\mathrm{mg}^{-1} \mathrm{~g}^{-1}\right)$; qmax is the maximum monolayer sorption capacity $\left(\mathrm{mg} \cdot \mathrm{g}^{-1}\right)$ and $\mathrm{K}_{\mathrm{L}}$ is Langmuir constant (L. $\left.\mathrm{mg}^{-1}\right)$.

From the slope and intercept of the Langmuir plot the values of $\mathrm{K}_{\mathrm{L}}$ and qmax were calculated and shown in the Fig. 7 and Table 2. The maximum sorption capacities were $17.37 \mathrm{mg} / \mathrm{g}$ and $9.4 \mathrm{mg} / \mathrm{g}$ for $\mathrm{Pb}^{2+}$ and $\mathrm{Cu}^{2+}$ respectively. It was clear that sorption process of both $\mathrm{Pb}^{2+}$ and $\mathrm{Cu}^{2+}$ on DDA$\mathrm{SD}$ followed Langmuir isotherm which was attributed to the fact that the sorption occurred through the formation of monolayer at homogeneous surface of the sorbent and there was no transmigration of sorbate particles during the process ${ }^{40}$.

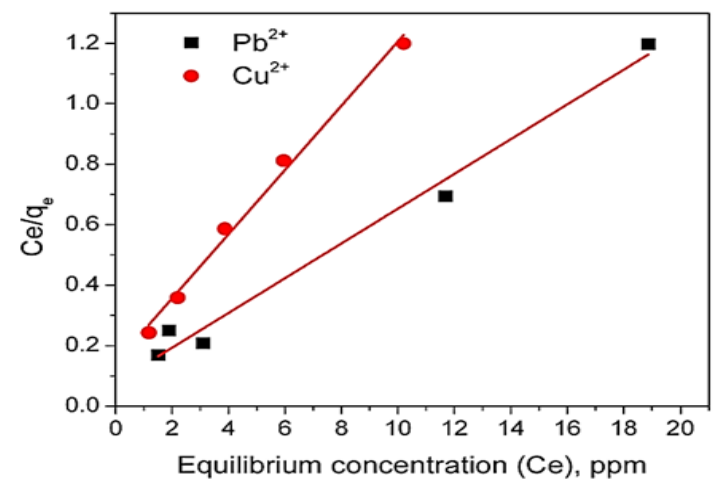

Fig. 7. Langmuir isotherms for sorption of $\mathrm{Pb}^{2+}$ and $\mathrm{Cu}^{2+}$ on DDA-SD

Table 2: Sorption parameters of Langmuir isotherms

\begin{tabular}{ccc}
\hline Parameters & $\mathrm{Pb}^{2+}$ & $\mathrm{Cu}^{2+}$ \\
\hline $\mathrm{q}_{\max }$ & 17.37 & 9.4 \\
Langmuir constant, $\mathrm{K}(\mathrm{L} / \mathrm{mg})$ & 0.743 & 0.745 \\
$\mathrm{R}^{2}$ & 0.9819 & 0.9904 \\
\hline
\end{tabular}

Table 3: Separation factor (RL) for the sorption processes

\begin{tabular}{ccc}
\hline Metal & Initial conc.(ppm) & $\mathrm{R}_{\mathrm{L}}$ Value \\
\hline $\mathrm{Pb}^{2+}$ & 9.5 & 0.1241 \\
& 10.5 & 0.1136 \\
& 18 & 0.0695 \\
& 28.5 & 0.0451 \\
& 34.6 & 0.0374 \\
$\mathrm{Cu}^{2+}$ & $20.6 \mathrm{a}$ & 0.0612 \\
\hline
\end{tabular}

a Langmuir isotherm was obtained from experiments using fixed initial concentration and different dosages of DDA-SD

A dimensionless parameter known as separation factor $\left(R_{L}\right)$ was obtained from the Langmuir constant, $\mathrm{K}_{\mathrm{L}}$ using the equation (4).

$R_{L}=\frac{1}{1+K_{L} C i}$

Where $\mathrm{C} i$ is the initial concentration of the metal ion $(\mathrm{mg} / \mathrm{L})$ and $\mathrm{K}_{\mathrm{L}}$ is the Langmuir constant (L/mg). 
$R_{L}$ values indicate the feasibility of the sorption process, thus $R_{L}=0,0<R_{L}<1, R_{L}=1$ and $R_{L}>1$ indicate that the process is irreversible, favourable, linear and unfavourable respectively. The values of $R_{L}$ in the present study were between 0 and 1 (Table 3) and indicated that the sorption process was favourable.

The sorption data were then evaluated for Freundlich model using the equation (5).

$$
\log q_{e}=\log K_{F}+\frac{1}{n} \log C_{e}
$$

The Freundlich constant, $\mathrm{K}_{\mathrm{F}}$ indicates sorption capacity, while $1 / n$ is a function of the energy of sorption process. It is evident from the Fig. 8 that the sorption process did not follow Freundlich isotherm model indicating that the processes did not proceed through the formation of a multilayer on heterogeneous surface ${ }^{40}$.

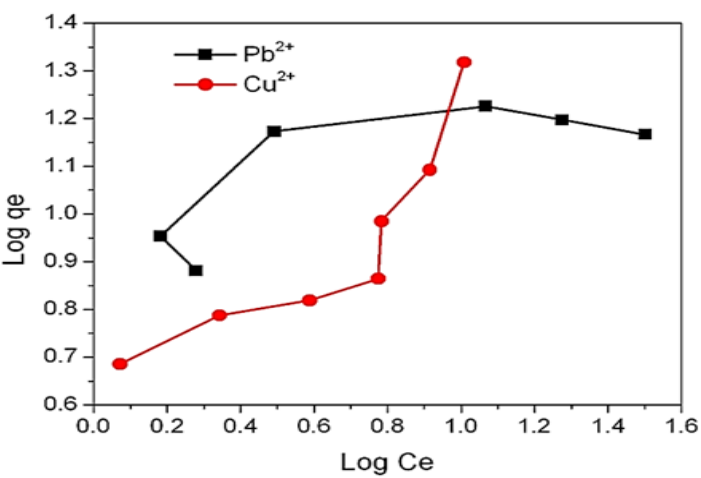

Fig. 8. Freundlich isotherms for sorption of $\mathrm{Pb}^{2+}$ and $\mathrm{Cu}^{2+}$ on DDA-SD

\section{Sorption Kinetics}

To understand the kinetics of the sorption of $\mathrm{Pb}^{2+}$ and $\mathrm{Cu}^{2+}$ on DDA-SD, the pseudo first order (equ. 6) and pseudo second order (equ. 7) kinetic equations were tested for the sorption data.

$\log \left(q_{e}-q_{t}\right)=\log q_{e}-\frac{K_{1} t}{2.303}$

According to the equation $6, \log \left(q_{e}-q_{t}\right)$ versus $t$ was plotted and observed that the sorption data for neither $\mathrm{Pb}^{2+}$ nor $\mathrm{Cu}^{2+}$ (not shown) matched with the first order kinetics (Figure 9).

$\frac{t}{q_{t}}=\frac{1}{K_{2} q_{e}^{2}}+\frac{t}{q_{e}}$

The second order kinetics model was tested by plotting $t / q_{t}$ versus $t$ and it was evident that the sorption of both $\mathrm{Pb}^{2+}$ and $\mathrm{Cu}^{2+}$ on DDA-SD perfectly followed this kinetic model $\left(R^{2}=0.9966\right.$ to 0.9998$)$. This means that the sorption rate depends on the metal ion concentration as well as the number of available active sites of the sorbent. The sorption capacities of DDA$\mathrm{SD}$ were calculated from the pseudo-second-order kinetics plots and listed in the Table 4 and found that the sorption capacities were similar to those obtained from Langmuir isotherm model.

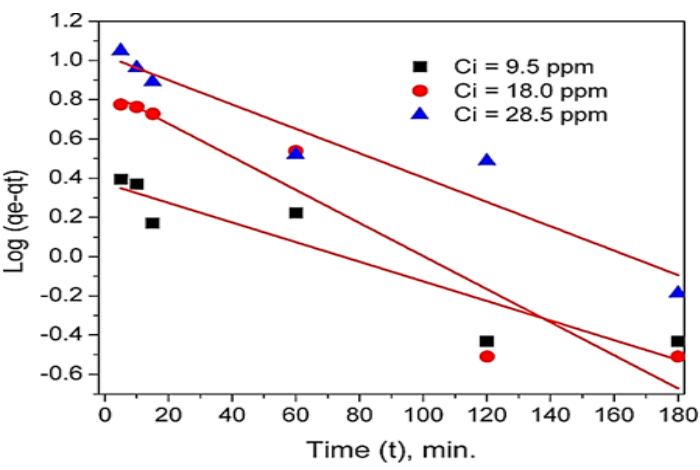

Fig. 9. First order kinetics for the adsorption of $\mathrm{Pb}^{2+}$ on DDA-SD
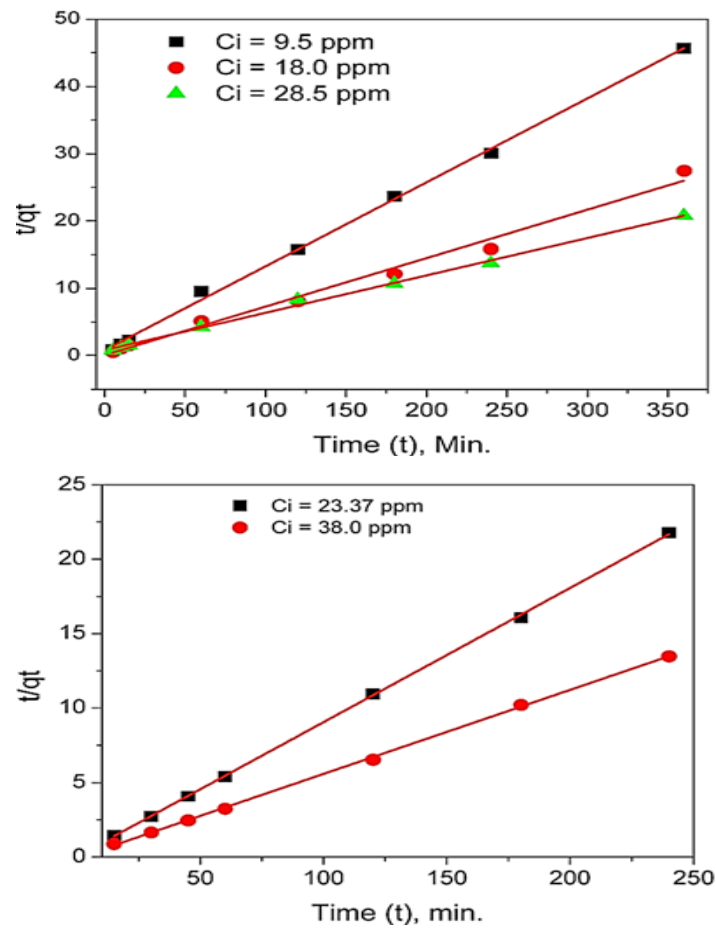

Fig. 10. Plot of second order kinetics for the sorption of $\mathrm{Pb}^{2+}$ (top) and $\mathrm{Cu}^{2+}$ (bottom) on DDA-SD

Table 4: Adsorption capacities of DDA-SD

\begin{tabular}{cccc}
\hline Metal & Initial conc. (ppm) & $\mathrm{R}^{2}$ & Ads. capacity, $\mathrm{q}_{\mathrm{e}}(\mathrm{mg} / \mathrm{g})$ \\
\hline $\mathrm{Pb}^{2+}$ & 28.5 & 0.9966 & 18 \\
& 18 & 0.9875 & 14 \\
$\mathrm{Cu}^{2+}$ & 9.5 & 0.9983 & 8 \\
& 38 & 0.9994 & 17.7 \\
\hline
\end{tabular}




\section{Regeneration}

In this study, regeneration of the sorbent was carried out by soaking $20 \mathrm{mg}$ of exhausted DDA$\mathrm{SD}$ in $20 \mathrm{~mL} 0.1 \mathrm{M} \mathrm{HNO}_{3}$ or $0.1 \mathrm{M} \mathrm{HCl}$ and leaving it for 30 min followed by wash with DI water. The desorption ratio (DR) was calculated as follows.

$\mathrm{DR}=\frac{\text { amount of metal ion }(\mathrm{mg}) \text { desorbed } / \mathrm{mg} D D A-S D}{\text { amount of metal ion }(\mathrm{mg}) \text { adsorbed } / \mathrm{mg} D D A-S D}$

After $30 \mathrm{~min}$ the desorption ratio was 0.97 for both the acid solutions used for regeneration purpose. Further increase in time decreased the desorption ratio, which may be due to the re-adsorption of the metal ions on regenerated DDA-SD.

The regenerated DDA-SD was reused for sorption of $\mathrm{Pb}^{2+}$ and it was found that in case of $34.0 \mathrm{ppm}$ solution the removal efficiency of regenerated DDA-SD was $30.4 \%, 29 \%$ and $27 \%$ for $1^{\text {st }}, 2^{\text {nd }}$ and $3^{\text {rd }}$ recycle while removal efficiency of fresh DDA-SD was $49.5 \%$. The decrease of removal efficiency of the regenerated DDA-SD is attributed to the reduction of active site due to protonation of the

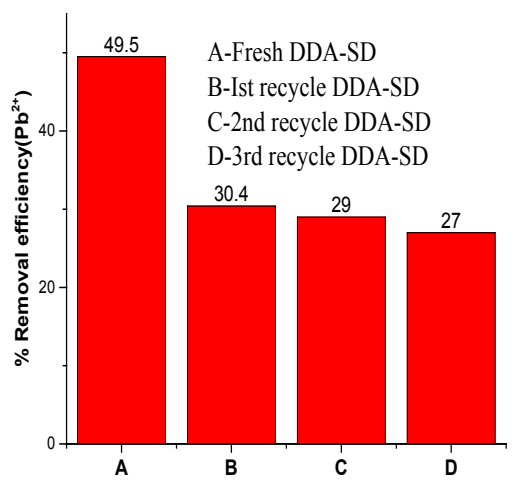

Fig. 11. Sorption of lead (II) ion on fresh and recycled DDA-SD
$\mathrm{NH}$ functional group in the acidic solution, which is assumed to be responsible for metal ion sorption.

In the present investigation sawdust of Albizia lebbeck was modified chemically and the sorption characteristics of the material were studied under equilibrium conditions using $\mathrm{Pb}^{2+}$ and $\mathrm{Cu}^{2+}$ solutions. The optimum $\mathrm{pH}$ for the sorption of $\mathrm{Pb}^{2+}$ and $\mathrm{Cu}^{2+}$ were 5.9 and 7.1 respectively. The sorption data fitted well to Langmuir model and did not fit Freundlich model at all. The maximum sorption capacities of $\mathrm{Pb}^{2+}$ and $\mathrm{Cu}^{2+}$ on DDA-SD were 17.37 and $9.4 \mathrm{mg} / \mathrm{g}$ respectively. The sorption data fitted well with the second order kinetic model. The exhausted DDA-SD was regenerated by treating with either $0.1 \mathrm{M} \mathrm{HNO}_{3}$ or $0.1 \mathrm{M} \mathrm{HCl}$ followed by washing with DI water and the regenerated DDA-SD showed acceptable sorption capacities.

\section{ACKNOWLEDGEMENT}

The research was supported by the Commonwealth Scholarship Commission in the UK. Thanks to the Ministry of Science and Technology, Bangladesh for financial support to one of the researchers. The authors are grateful to the Department of Applied Chemistry and Chemical Engineering, University of Dhaka, Bangladesh and the Division of Materials, Mechanics and Structures, Faculty of Engineering, University of Nottingham, UK.

\section{Conflict of Interest}

The authors declare that there is no conflict of interest.

\section{REFERENCES}

1. Ahalya N.; Ramachandra TV.; Kanamadi RD., Biosorption of heavy metals. Res. J. Chem. Environ., 2003, 7(4), 71-78.

2. Nouri J.; Lorestani B.; Yousefi N.; Khorasani N.; Hasani AH.; Seif S.; Cheraghi M., Phytoremediation potential of native plants grown in the vicinity of Ahangaran lead-zinc mine (Hamedan, Iran). Environ. Earth Sci., 2011, 62(3), 639-644.

3. Pagliuca A.; Mufti GJ., Lead Poisoning: an ageold problem. British Med. J., 1990, 300, 830.

4. O'Connell DW.; Birkinshaw C.; O'Dwyer TF.;
Heavy metal adsorbents prepared from the modification of cellulose: A review. Bioresour Technol., 2008, 99, 6709-6724.

5. Namasivayam C.; Ranganathan K. Removal of $\mathrm{Pb}(\mathrm{II}), \mathrm{Cd}(\mathrm{II})$ and $\mathrm{Ni}(\mathrm{II})$ and mixture of metal ions by adsorption onto waste $\mathrm{Fe}(\mathrm{III}) /$ $\mathrm{Cr}(\mathrm{III})$ hydroxide and fixed bed studies. Enviro. Technol., 1995, 16, 851-860.

6. Gueu S.; Yao B.; Adouby K.; Ado GW., Kinetics and thermodynamics study of lead adsorption on to activated carbons from coconut and seed hull of the palm tree. Intl. J. Environ. Sci. Technol., 2007, 4(1), 11-17. 
7. Nouri S.; Haghseresht F.; Lu GQM., Comparison of adsorption capacity of p-cresol \& p-nitrophenol by activated carbon in single and double solute. Adsorption., 2002, 8, 215-223.

8. Celis R.; Carmen HM.; Cornejo J., Heavy metal adsorption by functionalized clays. Environ. Sci. Technol., 2000, 34, 4593-4599.

9. Abollino O.; Malandrino M.; Sarzanini C.; Mentasti E., Adsorption of heavy metals on Na- montmorillonite effect of $\mathrm{pH}$ and organic substances. Water Res., 2003, 37, 1619-1627.

10. Oliveira LCA.; Petkowicz DI.; Smaniotto A.; Pergher SBC., Magnetic zeolites: a new adsorbent for removal of metallic contaminants from water. Water Res., 2004, 38, 3699-3704.

11. Zhang GS.; Qu J.H.; Liu HJ.; Liu RP.; Wu RC., Preparation and evaluation of a novel Fe-Mn binary oxide adsorbent for effective arsenite removal. Water Res., 2007, 41, 1921-1928.

12. Zhang GS.; Qu JH.; Liu HJ.; Liu RP.; Li GT., Removal mechanism of As(III) by a novel Fe-Mn binary oxide adsorbent: oxidation and sorption. Environ. Sci. Technol., 2007, 41, 4613-4619.

13. Robinson T.; Chandran B.; Nigam P., Removal of dyes from a synthetic textile dye effluent by biosorption on apple pomace and wheat straw. Water Res., 2002, 36, 2824-2830.

14. Saeed A.; Akhter MW.; lqbal M.; Removal and recovery of heavy metals from aqueous solution using papaya wood as a new biosorbent. Sep. Purif. Technol., 2005, 45, 25-31.

15. Babarinde NAA.; Babalola JO.; Sanni RA., Biosorption of lead ions from aqueous solution by maize leaf. Intl. J. Phys. Sci., 2006, 1, 23-26.

16. King P.; Srivinas P.; Kumar YP.; Prasad VSRK., Sorption of copper(II) ion from aqueous solution by Tectona grandis I.f. (teak leaves powder). J. Hazard. Mater., 2006, 136, 560-566.

17. Hanafiah MAKM.; Ngah WSW.; Ibrahim SC.; Zakaria H.; Ilias WAHW., Kinetics and thermodynamic study of lead adsorption onto rubber (Hevea brasiliensis) leaf powder. J. Appl. Sci., 2006, 6, 2762-2767.

18 Hanafiah MAKM.; Ibrahim SC.; Yahya MZA., Equilibrium adsorption study of lead ions onto sodium hydroxide modified Lalang (Imperata cylindrica) leaf powder. J. Appl. Sci. Res., 2006, 2, 1169-1174.

19. Johnson PD.; Watson MA.; Brown J.; Jefcoat IA., Peanut hull pellets as a single use sorbent for the capture of $\mathrm{Cu}(\mathrm{II})$ from wastewater. Waste Manage., 2002, 22, 471-480.

20. Bhattacharya AK.; Mandal SN.; Das SK., Adsorption of $\mathrm{Zn}$ (II) from aqueous solution by using different adsorbents. Chem. Eng. J., 2006, 123, 43-51.

21. Loukidou MX.; Matis KA.; Zouboulis Al.; Kyriakidou ML., Removal of As(V) from wastewaters by chemically modified fungal biomass. Water Res., 2003, 37, 4544-4552.

22. Atia AA.; Donia AM.; Abou-El-Enein SA.; Yousif AM., Studies on uptake behavior of copper(II) and lead(II) by amine chelating resins with different textural properties. Sep. Purif. Technol., 2003, 33, 295-301.

23. Gaballah I.; Goy D.; Allain E.; Killbertus G.; Thauront J., Recovery of copper through decontamination of synthetic solutions using modified barks. Met. Metall .Trans. B., 1997, 28, 13-23.

24. Nakajima A.; Sakaguchi T., Recovery and removal of uranium by using plant wastes. Biomass., 1990, 21, 55-63.

25. Sciban M.; Klasnja M.; Skrbic B., Modified softwood sawdust as adsorbent of heavy metal ions from water. J. Hazard. Mater., 2006, 136, 266-271.

26. Argun ME.; Dursun S.; Ozdemir C.; Karatas M., Heavy metal adsorption by modified oak sawdust: Thermodynamics and kinetics. J. Hazard. Mater., 2007, 141, 77-85.

27. Acar FN.; Eren Z., Removal of $\mathrm{Cu}(\mathrm{II})$ ions by activated poplar sawdust (Samsun Clone) from aqueous solutions. J. Hazard. Mater., 2006, 137, 909-914.

28. Ashwini A.; Udayasimha L.; Vyshnavi DR.; Usha HS., Comparative study on removal of copper from aqueous solution by modified and non modified sawdust adsorption. Intl. J. Pure Appl. Math., 2018, 120(6), 6709-6725.

29. Baral SS.; Das SN.; Rath P., Hexavalent chromium removal from aqueous solution by adsorption on treated sawdust. Biochem. Eng. J., 2006, 31, 216-222.

30. Taty-Costodes VC.; Fauduet H.; Porte C., Delacroix A., Removal of $\mathrm{Cd}(\mathrm{II})$ and $\mathrm{Pb}(\mathrm{II})$ ions from aqueous solutions by adsorption onto sawdust of Pinus sylvestris. J. Hazard. Mater., 2003, 105, 121-142. 
31. Bulut Y.; Tez Z., Removal of heavy metal ions by modified sawdust of walnut. Fresen. Environ Bull., 2003, 12, 1499-1504.

32. Choudhury TR.; Bhowmik S.; Rahman MS.; Nath MR.; Jahan FN.; Begum B.A.; Nurnabi M., Sythesis of Nano Zerovalent Iron Supported Sawdust (NZVI/SD) and Its Application for Removal of Arsenic (III) from Aqueous Solution. Chem. Sci. Int. J., 2020, 29(1), 1-12.

33. Haq AU.; Jan MR.; Shah J.; Sadia M.; Saeed M., A comparative sorption study of $\mathrm{Ni}$ (II) from aqueous solution using silica gel, amberlite IR120 and sawdust. Zeitschrift für Physikalische Chemie., 2019, 233(9), 1275-1292.

34. Ei-Saied FA.; Abo-Elenan SA.; El-shinawy $\mathrm{FH}$., Removal of lead and copper ions from polluted aqueous solutions using nano-sawdust particles. Intl J. Waste Resour., 2017, 7, 305.

35. Ogbu IC.; Akpomie KG.; Osunkunle AA., Sawdust-kaolinite composite as efficient sorbent for heavy metal ions. Bangladesh $\mathrm{J}$. Sci. Ind. Res., 2019, 54(1), 99-110.
36. Navarro RR.; Sumi K.; Fujii N., Matsumura M., Mercury removal from wastewater using porous cellulose carrier modified with polyethyleneimine. Water Res., 1996, 30(10), 2488- 2494.

37. Maekawa E.; Koshijima T., Preparation and characterisation of hydroxamic acid derivatives and its metal complexes derived from cellulose. J. Appl. Polym. Sci., 1990, 40, 1601-1613.

38. Yu W.; Bao-yu G.; Wen-wen Y.; Qin-yan Y., Preparation and utilization of wheat straw anionic sorbent for the removal of nitrate from aqueous solution. J. Environ. Sci., 2007, 19, 1305-1310.

39. Kamari A.; Ngah WSW., Adsorption of $\mathrm{Cu}(\mathrm{II})$ and $\mathrm{Cr}(\mathrm{VI})$ onto treated Shorea dasyphylla bark: Isotherm, kinetics and thermodynamic studies. Sep. Sci. Tech., 2010, 45(4), 486-496.

40. Hanafiah MAKM.; Ngah WSW.; Zolkafly SH.; Teong LC.; Majid ZAA., Acid Blue 25 adsorption on base treated Shorea dasyphylla sawdust: Kinetic, isotherm, thermodynamic and spectroscopic analysis. J. Environ. Sci., 2012, 24(2), 261-268. 